\title{
Do British and American Spellings Matter?: A Futuristic Construct
}

\author{
Kunlaphak Kongsuwannakul, Suranaree University of Technology, \\ Nakhon Ratchasima, Thailand
}

\begin{abstract}
This study aims to discuss general issues related to the difference in spelling between British and American English. It makes use of a small-scale survey of 160 university students in Northern Thailand as an initial source of orthographic variation existing in a new generation. Then, the discussion focuses on wider implications of spelling differences and plausible impacts on digitized texts, Internet search engines, social networks, publications and advertisements, and educational administration and curriculum design. Even though the two ways of spelling seem to simply represent two major mainstream English varieties in the world, i.e., those of the United Kingdom and the United States of America, the impacts in the long run can be claimed as far-reaching since they involve national pride and identity, a situation where one nation suppresses the other.
\end{abstract}

Keywords: World Englishes, British English, American English, Spellings, Discussion of Implications, Dynamic Model, Kachruvian Model, Social Network, Internet Users, Google, Search Engine, Popularity, Non-native Speakers of English

\section{Introduction}

$\mathrm{T}$

ALKING ABOUT SPELLING may seem somewhat trivial and unimportant with regard to textual interpretation and communication. In some cases like misspellings of, for example, newspaper vs. *newpaper or *newzpaper and actor vs. *acter, that could be true, especially when contexts of communication and interpretive circumstances allow a proper decoding in spite of some missing elements. However, in other cases where spelling, as part of a language system or a language variety, signifies a culture or society, which in turn represents a particular identity or 'self', it would not be as simple as we may have thought.

At this point, some discussion of the significance of spelling and identity. Just like accent, spelling can generally show certain aspects of the way we are. For example, an employee who usually spells words wrongly could be readily perceived as reckless, badly-prepared or even 'poorly educated' by his/her boss, which can very plausibly somehow affect his/her career advancement. A hotel receptionist could quickly identify her customer as a Briton from his stress-timed accent and his note writing 'Carnegie Centre' for a taxi call. The art of spelling itself can render big events like a National Spelling Bee competition in the U.S. with millions of audiences watching the broadcast in prime time (Associated Press, 2011). Spelling, together with grammar and composition skills, can also show whether or not an applicant for a job is well-qualified, just like what we can find, for example, from the comments made by the Mark \& Spencer chairman who has been reported complaining a lot of "young people leave school "not fit for work" (Paton, 2010, para. 4), particularly as a result 
of their being unable to "compose a sentence, spell difficult words or write a coherent letter or email" (ibid., para. 2).

Given the above point of view, I am intrigued and therefore exploring the issue of spelling so as to see whether this seemingly small aspect of language can pose big challenges on a global scale or, at least, represent larger issues relating to a global phenomenon. Considering the current situation of widely, and rapidly spreading, use of English language worldwide moving toward an unavoidable and indisputable status quo for English as a world language (e.g., Crystal, 1997a; Schneider, 2007), I choose to investigate a fundamental yet delicate question about differences in spelling between the two major English varieties: British English and American English. These two varieties of English - or actually two Englishes if we would allow a new usage of the word 'English' as a countable noun (Try searching for 'Englishes' in www.google.com, and some 104,000 results will return, with many of these from reliable, academic websites) - are selected because "[w] hile these [American and British English] are by no means the only two types of English used around the world, most varieties of English take their lead from one of these two" (Jones, para. 2, cited in Byrd, 2001). This should suggest a high power of generalization and inclusion of the discussion here when it is based on the two varieties. All in all, the primary objective of this paper is to examine the potential impacts of difference in spelling between British and American English on global issues.

\section{Survey into a Next Generation's Spelling}

To depict the current situation of English spelling preference, which will enable a discussion of futuristic issues to continue further in this paper, a small-scale survey from an English as a foreign language (henceforth EFL) country will be first summarized here.

Thongkhamkhao (2010) carried out a survey on preference for a spelling style, with an emphasis on British and American English. Her sample consisted of 160 undergraduate students of Thai nationality at a public autonomous university in northern Thailand. They were from ten academic schools, with arts and science disciplines mixed almost equally. She used a specially created test to collect the data of spelling styles from them. The test was composed of fifteen items, each requiring the subjects to fill out the latter part of a word which is normally spelled differently in the two varieties of English and which she expected the subjects would know. The fifteen words were organize, apologize, color, colonize, favorite, neighbor, honor, kilometer, program, globalize, catalog, center, realize, behavior, and dialog (For the sake of discussion and consistency, I use the American spelling style throughout unless otherwise required). The first five items are cited in Figure 1 below as examples of the test items: 
1. He began to orga___ his materials.

2. I apolo___ for being late.

3. Green, red, and blue are col

4. Cambodia was colon___ by France in the past.

5. My fav___ football team is Manchester United.

Figure 1: Examples of Test Items for Surveying Preferences in Spelling Styles

(Thongkhamkhao, 2010, p. 14)

Her hypothesis that the subjects would prefer American spelling to British spelling proved positive. She counted all the 2,400 elicited answers ( 160 students multiplied by 15 test items) and assigned each answer into either American or British spelling category. Overall, 84.63 of the answers could be ascribed to American spelling style, 14.48 to British one, and 0.89 to unknown/indistinguishable style (e.g., due to illegible handwriting or elicitation of a different, undesired word part altogether). With no need for advanced statistical analysis of the data, she concluded that the power of American English was simply significant and pervasive in that generation of the university students.

Regrettably, Thongkhamkhao (2010) did not discuss the possible future of this spelling preference nor its likely impact upon the EFL spelling style in Thailand or in other similar countries, but chiefly gave a short post hoc explanation for the students' American spelling preference. Still, there is an initial implication from her study that I can make in this step: very plausibly, these students, once having graduated from the undergraduate level of education, will continue to carry this spelling style - which is almost exclusively American - to their future use unless they choose to change or there are people telling them to do so. In short, this spelling-related discovery from EFL users at the tertiary education level suggests the American spelling style would be widely used in the near future, at the very least in Thailand.

\section{Result Implications under the Model of Three Concentric Circles}

In this part, I will take the above findings of Thongkhamkhao's study into a reinterpretation under Kachru's (1992, referred to in Jenkins, 2003) model of the three circles of English (See Figure 2). 


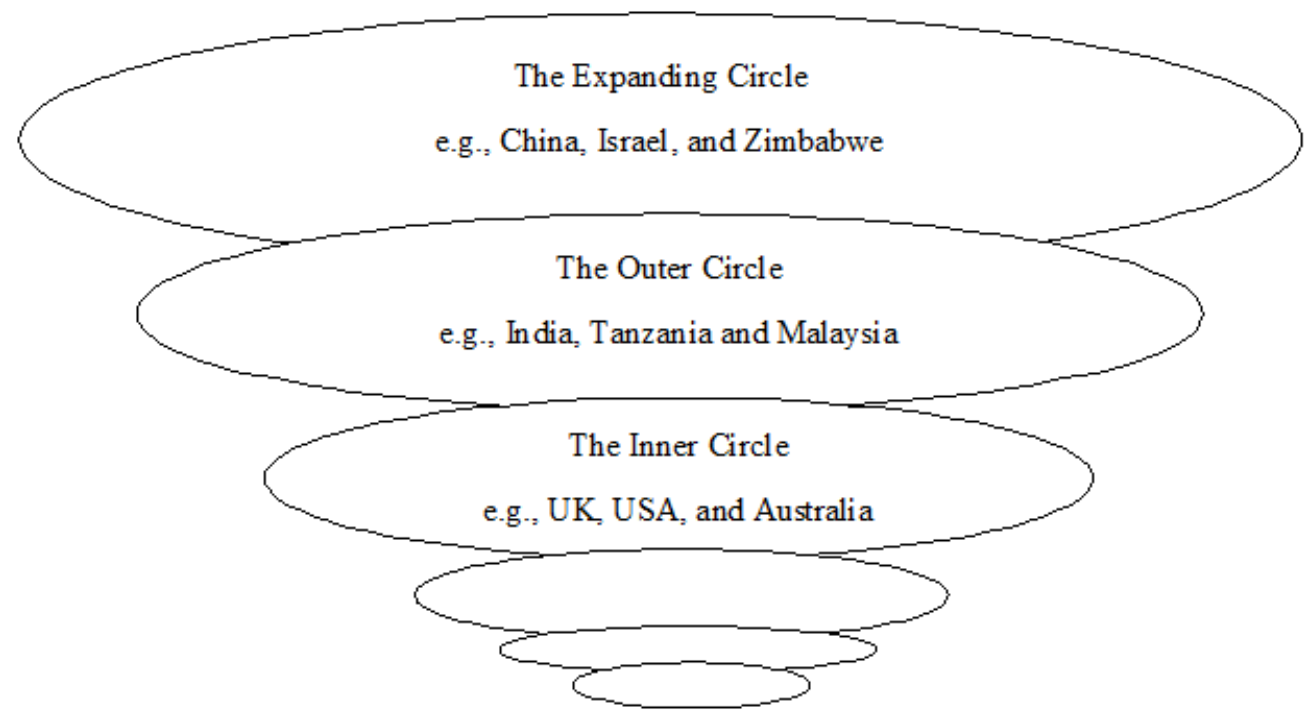

Figure 2: Kachru's Three-circle Model of World Englishes (Adapted, Jenkins, 2003, p. 16)

From Figure 2, the inner circle represents countries where English is a native, official language (ENL). People in this circle speak English in all aspects of life. The outer circle represents countries where English is a second, official language (ESL). English is used extensively and taught as compulsory foreign language to children whose first language is a different one. The expanding circle represents countries where English is used as a foreign language with no official status (i.e., EFL). Yet, due to importance of English broadly recognized nowadays, the language is often taught in these countries to the children at their early age.

The model has been commented by several scholars (e.g., as reminded by Dewey \& Jenkins (2010) and Omoniyi \& Saxena (2010)) in such a way that it fails to recognize a) the English as a lingua franca (henceforth ELF) communicative situations where both native and nonnative speakers can take part and b) the globalized world community with "open borders, human migration and transcultural flows facilitated by new media" (Omoniyi \& Saxena, 2010 , p. 5). Nevertheless, this model, in my point of view, can still give us an approximate, fundamental idea of how the English language is being used worldwide with the number of non-native speakers vastly outnumbering that of the native speakers. In other words, the main drawback to this Kachruvian model is that native and non-native speakers seem to be completely separated by the borders of countries despite the fact that English as an international language (henceforth EIL) communicative situations often combine inner circle and/or outer circle English speakers (ibid.). Nevertheless, a clear depiction of the larger number of non-native speakers of English than that of ENL speakers is unquestionable.

Considering that the enormous number of ESL and EFL users really matter, be it politically, economically, or socially, from the model we can therefore assume that 328,000,000 native speakers of English nowadays (Lewis, 2009; 337,407,300 people in Crystal, 1997a) are totally outnumbered by "nearly a billion people around the world speak[ing] English" (Tapia, 2010, para. 2; 2,024,614,000 people in Crystal, 1997a), especially when it comes down to the power of negotiation and dissemination, which I will discuss later. That is to say, if we 
base our counting on Crystal's statistics, non-native speakers of English in the world are around almost 1.7 billion in number (the total 2,024 million minus 337 million). This, of course, amounts to approximately one-fourth of the world's current population $(6,892,319,000$ people in Population Reference Bureau, 2010, p. 2).

Apart from the implication of the considerable number of non-native speakers of English that can be made from Kachru's model of the three concentric circles, another implication is about the inner circle itself. As there are only a handful of countries in the inner circle, i.e., the United States, the United Kingdom, Australia and only a few more, it could therefore be held that the country with the majority of ENL population plausibly has the highest power of dissemination of idea and, of course, spelling style in this era of globalization. According to Population Reference Bureau (2010), the United States of America population is about 309.6 million people, the United Kingdom 62.2, and Australia 22.4. Note also that in these countries, a fractional number of people are non-native speakers of English, some immigrants, others descendents of native origin. Taking a quick glimpse at these numbers, undoubtedly ENL American people seem to be the most potential 'carriers' of their corresponding spelling style.

As a result, it can be concluded on the basis of the Kachruvian model that the American spelling preference of the next EFL generation discovered in Thongkhamkhao's (2010) survey is nothing but a realistic manifestation of the capability of American people for diffusing their orthographic variation. This capability seems to permeate into a large number of ESL and EFL users, who in turn make the majority of the world's English users. It, of course, should be noted here that the world or, to put it specifically, countries in the world nowadays are intertwined in one way or another; the American spelling preference existing in a Thai young generation should reflect such a preference in similar circumstances (i.e., EFL countries and, very plausibly, ESL ones) to a certain degree.

\section{Reinterpretation under the Dynamic Model}

In the earlier section, the Kachruvian model is used as a basis for discussion. The model groups English-using countries into three categories in accordance with their range and depth of English use by the majority of a country's population. From my understanding, a consequence of the model for studies of the English language is that it has raised awareness of and thus brought into focus "individual varieties, their features and conditions of use" (Schneider, 2007, p. 29). That is to say, world Englishes researchers-having recognized the plausible variation from one English variety to another - usually put emphasis on "the polymorphous character of the world's Englishes" (Dewey \& Jenkins, 2010, p. 74). Recently, however, there has been a model which has been projected as an effort which is "more ambitious in claiming that there is a shared underlying process which drives their [postcolonial Englishes'] formation, accounts for many similarities between them, and appears to operate whenever a language is transplanted" [italics mine] (Schneider, 2007, p. 29) and which I find useful and interesting for explaining and predicting the British and American spelling variation being explored here.

To facilitate the general audience, let me first summarize the Dynamic Model by Schneider (2007). The model is stated to have a basis on "identity rewritings and associated linguistic changes" (p. 30) and "the ethnographic ecology of the sociopolitical and, consequently, communicative relationship between the parties involved in a colonization process" (p. 31). 
It consists of

1. five stages of diachronic development of an English variety:

1.1 foundation,

1.2 exonormative stabilization,

1.3 nativization,

1.4 endonormative stabilization, and

1.5 differentiation, and;

2. two strands of communicative perspective (i.e., settlers and indigenous people).

In the phase of foundation, when settlers bring English into a new area or territory, English is in contact with indigenous language, thereby causing a leveling or simplification of language. In the next phase exonormative stabilization, a settled community of native speakers of English sets the usage, seeking their identity and, certainly, the standard of the language from their home country. In the third phase, English, which has gradually changed itself towards a local language norm, is nativized, with a smaller gap between the settlers and the local people. The English language in this stage, therefore, shows a clear acculturation and linguistic accommodation to the local language. It undergoes a big change in terms of vocabulary, sound system, and structure. In the fourth phase of endonormative stabilization, mostly with political independence and "cultural self-reliance" (p. 48), a new variety of English can be readily perceived. Reference books using this new form of language can be found in this stage, e.g., A Compendious Dictionary of the English Language by Noah Webster in 1806 (Merriam-Webster, 2011, para. 1) for American English. In the final stage differentiation, the focus of identity is shifted from a collective community like a nation to a "smaller, sociolinguistically determined" group (Schneider, p. 53). Regional variation or dialects emerge in this stage, collectively covered by one umbrella-like national identity (op. cit.). Schneider takes American English as an example of an English variety that has been through all these five stages (Chapter 6).

Returning to Thongkhamkhao's (2010) discovery of American-preferring spelling style belonging to Thai undergraduate students, I find this non-native variety of English in the stage of exonormative-cum-nativization along this cline of an English variety's evolution by Schneider (2007). This is due to the fact that English language teaching in the country still seeks standards from either American or British English. In other words, the Thai users of this non-native English variety still define themselves as EFL users and thus rely on an external standard of English, which appears to be largely American. Nonetheless, according to Kongsuwannakul (2005), the English language in Thailand has actually been undergoing nativization, only in certain language domains of personal space though. This suggests that at the EFL level — where the majority of English-using world population resides - a native standard of the English language, spelling style definitely included, is still a common yardstick even though nativization and acculturation are happening gradually.

Implying from what Thongkhamkhao (2010) has found, it is highly probable that American English is taking a stronger hold of the exonormative stabilization process on a global scale, particularly over Kachru's (1992) expanding circle. This triumph can therefore yield a far-reaching result: non-native varieties are on their way to endonormative stabilization with American English spelling playing a prominent role. Eventually, when sense of belonging 
is heightened with an EFL country's identity vigorously formed, it is likely that American spelling will be a primary basis for setting its own spelling style.

It should be noted here that the stages of exonormative stabilization and nativization are essential steps that will lead to the phase of endonormative stabilization, which entails "a new, locally rooted linguistic self-confidence" (Schneider, 2007, p. 49). Put briefly, whatever features distinct and pervasive in the earlier stages tend to continue and thus likely be rooted in the end. Take the evolution of American English itself as a clear example. Somewhere during the mid-eighteenth century, American English was on the way to nativization through linguistic leveling and homogeneity, a situation usually called a melting pot and having started to exist since the stage of foundation (Schneider, pp. 260-269). The homogeneity and increased uniformity in language use of people of different, various backgrounds led the language to the point where such features were consolidated and codified (Phase 4) when sociopolitical circumstances for identity revision allowed. The Independence Declaration on July 4, 1776 seemed to be a significant milestone for nativized identity construction of American English, turning a variety of once "British standard $[\ldots]$ as the defining variety of correct English" (Algeo, 2001, p. 19, cited in Schneider, 2007, p. 266) in the phase of exonormative stabilization into a "self-confident" (Schneider, p. 285) and autonomous standard-setting English variety in the stage of endonormative stabilization. In short, uniformity in language use of American English changed a dependent, subordinate English variety into a self-reliant one.

On the basis of the Dynamic Model by Schneider (2007), an implication of the pervasive American spelling preference existing in the new EFL generation, therefore, lies in the potential that when an EFL variety develops to the endonormative stabilization stage in the future, this American spelling style will be agreed upon by the majority of the EFL users and probably codified in the form of printing and publication. The codification will in turn reinforce and strengthen the usage of other members of their corresponding community/territory, thereby minimizing, if not eliminating, the variant forms. However, note also that when the internal norms are emphasized, it does not necessarily mean variation will no longer persist within the society. Instead, internal variation will just continue with less significance in the stage of endonormative stabilization.

\section{Implications: From Personal Space to Global Community}

In the earlier sections, spelling differences-in which American English spelling style is found far more popular among a sampled group of EFL users than British English one- are discussed. The implications are based on two models in the field of world Englishes, one helping in a way to explain a de facto power of American English over British English and thus its power of dissemination, the other predict a plausible impact of American English on EFL identity rewriting in the future. The discussion suggests that American English, with particular reference to its spelling, has been quite successful in cultivating its style of spelling among EFL users and this will yield long-lasting impacts on the seeking of their style of English together with other related issues in the future (For details about American English development and its immense sociopolitical and economic power, see Baugh \& Cable (1993), Chapter 11, and Crystal, 1997b, for example). In this section, I therefore will discuss the plausible impacts in detail. 


\section{An Identity Formation and Reformation}

In the section Reinterpretation under the Dynamic Model above, I introduce the model by Schneider (2007), which is claimed to be constructed on identity rewriting, ethnographic and sociopolitical contexts, and communicative situations. It can consequently be implied that identity and perception and presentation of identity can influence the way we use our language to a certain degree. Use of identity-related concerns should then be a fine starting point here.

Identity is what people constantly feel and struggle to express. Anecdotal evidence can illustrate the notion. T. Saengakart, a graduate student at a large university in Thailand, told of an American classmate studying English language studies who has reportedly been 'insecure' about 'her language' in such a way that it has been made corrupt by non-native users of English around the world, certainly those in Thailand included (personal communication, May 6, 2011). Regardless of considering the actual history of the English language - which was introduced to the now British Isles approximately in the fifth century A.D. (Baugh \& Cable, 1993) - we can see that language can create even a sense of belonging and thus loyalty or jealousy (i.e., extreme carefulness in protecting something). It can become a property one wants to protect and keep as is (Cf. Baugh \& Cable (1993), Chapter 9, and Bryson (1990), Chapter 9 for examples of often fruitless attempts to 'purify' language).

Language and the usage of language in a particular style can of course denote the self we would like others to perceive. For example, the 'single status' of Facebook accounts in America is alleged to be of a large number of people, married people included (Thianthai, 2011, cited in Matichon Online, June 30, 2011). Clearly, being single is what is desired by such Facebook account owners and thus perceived by the other online community members.

According to Thianthai (2011, ibid.), there are three types of self in psychological terms: actual self, ideal self, and ought-to self. In the 'single status' case of Facebook owners mentioned above, the ideal self is what most people try to express and sometimes becomes problematic. This is due to the fact that the construction of an ideal self can affect the actual self and vice versa. To put analogously, daydreaming can have an effect on work efficacy to a certain degree. Likewise, infidelity in various forms by celebrities or politicians, for instance, often appears a news headline or a common social phenomenon (implied in Thianthai, 2011) when their ideal self takes control over awareness of their own actual self and oughtto self. In short, their ideal self construction by means of such language use somehow leads them to infidelity. Language use, consequently, could be ascribed to and concomitantly bring out the manipulation of a self construction.

Returning to our issue of spelling variation, it can therefore be asserted that the spelling style that a person has been using may likely be sustained or fossilized owing to his/her sense of belonging and protection. People's spelling style is part of their identity and thus property.

However, when spelling is involved with the ideal self that a person wishes to display to the others, a particular style of spelling can become tricky. For instance, a blogger from Britain - fully aware:

1. that the target audience of his article on nutritious imbalance in American fast food is international in nature due to the worldwide feature of his online weblog and;

2. that, consequently, his American readers will benefit more if the article is easily accessible to them via search engines (which I will elaborate in the next section) - may choose 
to use American English spelling so that the article can more likely be on the very first few pages of online search results.

Plausibly, his constant exposure to American English spelling style may partially contribute to his decision to change (or not to change) the spelling style of his blog writing since-apart from the two points concerning awareness above - a sense of belonging to a particular community (the international characteristic of which will likely show an inclination towards American English) can also play a role. Note that by changing the style, this writer's identity is affected and deviated. In other words, his ideal self is in conflict with his actual self.

Apart from the plausible conflict on the writer's (or textual encoder's) side, when a person takes part in a community, be it online or print, a style of spelling is also one of the things the person is likely to encounter when exploring the community's language. The exposure can be at both the conscious and subconscious levels. Just like my example of the blogger above, as long as American English spelling style is expanding in terms of popularity and power, we will likely have a higher exposure on it when going through online as well as print texts. Gradual change in the ought-to self can also be seen even from British English users. Examples include a compilation by Upward (1997), where the Simplified Spelling Society wrote to Britain's School Curriculum and Assessment Authority, pressing that:

We have here surveyed the majority of Anglo-American spelling differences, and we have noted that nearly all offer patterns where the American conventions are in every respect, or at least in important respects, to be preferred. Britain thus does itself a disservice in many ways if it tries to resist such American spellings. British children frequently encounter American spellings on television and elsewhere, and they naturally prefer simpler, more phonic forms that better suit their pronunciation and the wider regularities of English spelling. To insist that they reject spellings which they commonly see, and which come more naturally to them, at best discourages children, and at worst causes them real distress. The irregular spelling of English does incalculable damage to educational standards in general, but a more enlightened attitude towards American spellings in Britain (and in those parts of the world where the British tradition has taken root) would tend slightly to reduce the problem [italics mine] (Section 11).

Given that American English has enjoyed a far greater success:

1. in modeling the spelling style of the majority of the English-using world (especially the expanding circle; cf. the earlier section Survey into a Next Generation's Spelling) and;

2. as a consequence, in providing the lead to the American spelling-preferring community, the exposure of the English spelling of the 'other' style (i.e., British spelling) should be in the opposite direction: British English spelling can reach people to a lesser extent. That is, American English spelling and British one are competing for information and media space on a global scale, and the former is likely to claim a bigger share.

Moreover, considering that American English is taking a superior position to British English as argued throughout the current paper, American bloggers, for example, would not likely change their spelling style into the British one. This is totally a stark contrast to the situation 
of two types of self in conflict considered above. In this case, they will simply try to maintain their actual self and identity.

All in all, it can be summarized that the expression of a self shapes and simultaneously is shaped by the community a person is in contact with. Just like immigrants soon adopting an accent closer and closer to that of the people in that community, the more one has exposure to American spelling, the more likely the spelling style would have an impact on identity reformation. Given that American spelling is in a more advantageous position, fueled by its triumphant dissemination among non-native users of English, a one-directional growth of British-to-American spelling popularity can be predicted with certainty to occur.

\section{A Reflection from the Virtual World Community}

As has been argued, the number of American spelling users is fast growing, thanks to the use by both its own native speakers and non-native speakers of English. In this era of globalization and internet (not even to mention 'Googlelization', a term closely associated with Americanism), a digital, online observation of this global phenomenon should plausibly depict the perception and, hopefully, understanding of the situation through the lens of popular culture to some, if not a large, degree.

According to Times Higher Education's world university rankings 2010, there are 72 United States universities ranked high in the list of 200 top universities (Thomson Reuters, 2011), ascertaining the validity of the earlier exploration here in such a way that American spelling is in a better position for dissemination of its thoughts and, certainly, spelling style to the eyes of the world's populace. Moreover, all of these universities nowadays encourage an online application for admissions to their programs. This kind of requirement may look superficially somewhat irrelevant to the issue under discussion unless we 'google' for web pages.

To elucidate a de facto challenge of spelling variation existing in the virtual world, a few examples will do. From a basic website search through the well-known search engine Google (on July 7, 2011, to be specific due to the fast-changing nature of the internet), a search for "graduate programs" yields around 7,310,000 results while the one for "graduate programmes" only 964,000 results. In addition, a search for "center for" provides $221,000,000$ search results, but a search for "centre for" returns merely 79,000,000 results. Clearly, this elucidation shows both the power of spelling diffusion and the popularity of the American spelling style (or, at the very least, American-preferring spelling style for non-native users of English) existing in the online world. When a person searches the internet by means of one of these two words, for instance, he or she will obtain more options of web pages to choose.

To set the application boundary of this argument, let me cite the words that this way of searching will likely be applicable to. In Longman Exams Dictionary (2006), an international edition by the British-based company Pearson Longman, there is the Longman Defining Vocabulary list (pp. 1818-26) with approximately " 2,000 common words [that have] been used to write all the definitions in this dictionary. The words in the Defining Vocabulary have been carefully chosen to ensure that the definitions are clear and easy to understand, and that the words used in explanations are easier than the words being defined." (p. 1818). It can hence be implied that these 2,000 words are in common recognition and understanding and thus in wide use by the users of English in general. Consequently, words that are less frequently used and spelled differently in British and American English like oestrogen vs. 
estrogen, and valour vs. valor will be ruled out of the search on the grounds of basic fairness and appropriateness in terms of popularity.

From my going over the whole list, I find altogether 23 word entries that can be ascribed chiefly to the British English spelling style or to different spellings in the two varieties of English. They are advice, advise, centre, cheque, criticize, defence, emphasize, grey, humour, kilometre, litre, metre, offence, organise, organization, practice, practise, program (n), programme, realize, recognize, skilful, and theatre. Note that they are presented here with their original forms also displayed in the list of the dictionary. It can also be remarked that some of them (e.g., emphasize and recognize) look more like their American counterparts already, signifying that their truly British forms are being used with less frequency and, plausibly, popularity in the Longman Corpus Network, "a huge database of 330 million words from a wide range of real-life sources" (Pearson Longman, n.d., para. 1) which the dictionary is based on.

I then narrow down the pool of these words into 17 words, discarding the words advice, advise, cheque, practice, and practise altogether to avoid duplicate results from a Google search owing to their varied forms between a noun and a verb in British English but single forms in American English. The search for the frequency of the rest yields the following results:

Table 1: A Comparison of Search Result Numbers of Selected Words between American and British Spellings, Based on the Results of July 9, 2011

\begin{tabular}{|c|c|cc|}
\hline American spelling & Search results & British spelling & Search results \\
\hline $\begin{array}{c}\text { center } \\
\text { criticize }\end{array}$ & $3,990,000,000$ & centre & $1,550,000,000$ \\
defense & $26,000,000$ & criticise & $7,450,000$ \\
emphasize & $481,000,000$ & defence & $186,000,000$ \\
gray & $49,000,000$ & emphasise & $9,210,000$ \\
\hline humor & $625,000,000$ & grey & $763,000,000 *$ \\
kilometer & $679,000,000$ & humour & $184,000,000$ \\
\hline liter & $92,600,000$ & kilometre & $27,300,000$ \\
meter & $185,000,000$ & litre & $71,500,000$ \\
\hline $\begin{array}{c}\text { offense } \\
\text { organize }\end{array}$ & $829,000,000$ & metre & $65,800,000$ \\
\hline $\begin{array}{c}\text { organization } \\
\text { program }\end{array}$ & $105,000,000$ & offence & $39,600,000$ \\
realize & $196,000,000$ & organise & $79,000,000$ \\
recognize & $816,000,000$ & organisation & $382,000,000$ \\
\hline skillful & $2,940,000,000$ & program me & $522,000,000$ \\
\hline theater & $356,000,000$ & realise & $86,700,000$ \\
\hline Total & $218,000,000$ & recognise & $45,800,000$ \\
\hline & $39,600,000$ & skilful & $17,200,000$ \\
\hline
\end{tabular}

From Table 1, it is obvious that American spellings of these 17 words, when searched for through the most powerful search engine Google, are almost exclusively popular than their 
counterparts in British English. The only exception is American gray, which seems to need somewhat more uses to overcome its counterpart, British grey. Overall, the total difference of these words in terms of 'popularity' through the search engine is approximately $170 \%$ (i.e., $12,206,200,000$ vs. 4,527,560,000).

Of course, the illustration via the numbers of the 17 words above is not everything; it just gives a rough idea of how much difference the words bear in terms of the number of use and occurrence in websites on a global scale. These examples, however, confirm for one thing that were a non-native user of English to choose a spelling style for, say, the online announcement and advertisement of an academic program or an organization (if not 'organisation' though), there is a general tendency that American spelling would be a more promising choice since it can more likely enable both 'the publishers' and 'the finders' to join the same community. Website descriptions with American spelling will be those which could be 'found' or 'hit' by a search engine first if non-native speakers of English — who may have been largely influenced by and very likely exposed to American spelling rather than British one during their internet surfing and English language learning (Cf. the quote by the Simplified Spelling Society in the above section an identity formation and reformation for a perspective from an educator) - are going on the internet and searching with a specific wording of different spellings.

However, note that such differences in search results are still restricted to a handful of words and compounds of these words (frequently used ones though). My point, therefore, is simply to present some plausible variation on the basis of statistical comparison, neither to judge the value of a particular spelling variety nor to offend the parties involved.

Another point that should be added here is the significance of a powerful and thus popular search engine acquired in the online world. Not only can this signify the advantage over the media coverage and public space, but it also means a lot of profits and/or accessibility of the websites which have higher 'user-friendliness'. Plausibly, this is a reason why a large corporation like Microsoft is putting a lot of effort just to reach more and more internet users, as we can see from a piece of recent news where collaboration between Microsoft and Baidu, a big search engine corporation in China with approximately 75 percent of the country's market share, has been announced, with Microsoft's view to penetrating the largest internet market in the world (Matichon Online, July 5, 2011). Obviously, both online space grasp and accessibility are simply indispensable when the number of websites and web pages in the world is increasing steadily.

Moreover, it should be reiterated that searchability is what is essential to build up in the virtual world since the world, metaphorically, can also revolve around the internet users. According to Moeller (2011), internet users - particularly students (in her term, young adults) who are regular members of Facebook, Twitter, Skype IM, QQ, Weibo, RenRen, text messaging, social media, chatting, and e-mailing - "inhale, almost unconsciously, the news served up on the sidebar of their e-mail account, posted on friends' Facebook walls or delivered by Twitter" (p. 14A) and, of course, by means of other social network sites where information is provided directly to them. In a way, this implicitly supports the earlier argument of spelling reinforcement through constant exchange of information with people a person is in contact with. Yet, the other inference worth considering is that "users went to pages and sites that told them exactly what they wanted to hear" [italics mine] (ibid.). That is to say, it is also the internet users that can choose what to consume by "commonly visit[ing] specific sites they ha[ve] identified for news and entertainment" (ibid.), thereby in turn strengthening 
their familiarity with and their tendency to use and, unknowingly, share a particular style of spelling with their social network members. These young adults go to specific information - with a particular spelling style as part of their searching, definitely — and then share it with their regular community members, who, of course, would care "about what their friends [are] up to" (ibid.). In short, the new generation of internet users is both selecting the information sources and their corresponding spelling style they have had in mind and spreading them to their friends. As discussed earlier, again, these young adults are forming their own identity and thus partly reforming or strengthening their friends' identity.

\section{A Decision to Make in Contact with the Outside World}

As discussed earlier, American spelling seems, on the basis of a good deal of evidence, to be popular as well as powerful due to America's past and, very plausibly, current glory in sociopolitical and economic terms. There is a clear tendency for young generations of ESL and EFL users to have their American spelling at their disposal in a large proportion. The success can in turn reinforce their community members' absorption and selection of the American spelling. One primary issue is, therefore, whether the users of British spelling will ever resist such a tidal wave of American spelling blow in this current era of Americanism.

To answer the question should be a matter of time. In one aspect, some British English native speakers have set out to welcome American spelling as a less confusing choice for learners (Upward, 1997; Cf. the section An identity formation and reformation above), and such aforementioned global phenomena as the popularity of American spelling among nonnative users of English can easily confirm the American-preferred spelling direction. Nonetheless, to witness the British government's acceptance of American spelling for all its levels of language use in the British Isles-which will indicate a complete defeat in this spelling 'competition' and a starting point for the whole single-spelling-style-for-all-countries outcome - seems to be an impossible thing. As we all know, language and power are closely intertwined and, just like discussion by Bryson (1990), language can often be an emotive issue, where many governments could be even "brought down" (p. 40). Any British government to admit the defeat that way, even for the good of educational and publishing industries, will be only on the way to suicide. Such an action will surely backfire owing to the sense of identity retention and patriotism.

Then, how will this competition of spelling variation end, say, for the next ten years? In my way of thinking, the one directional British-to-American change (Cf. the above section An identity formation and reformation) will gradually intensify due to the power of global media and information technology, since "[m]ovies, television, books, magazines, record albums, business contacts, tourism [and certainly internet and steadily growing social network and new media] —all these are powerfully binding influences" (Bryson, 1990, p. 245) and, of course, significant reinforcement for American English, which has won the majority of the coverage. And the outcome will be that British spelling will win a smaller share of its spelling lead and likely become just a variety of English, no longer providing as a mainstream spelling standard.

We, definitely, will need to 'wait and see' whether the construct will prove positive or not. Still, there are signs that British English is really going into that direction. Lately, for example, universities in England have been reported preparing to increase their tuition fees despite students' vow to continue their protest against this policy (Harrison, 2010, Dec 10). 
The situation can suggest two important implications to our discussion. First, the U.K. has also been so badly affected by the Eurozone debt crisis that there is an undesirable impact even on the education of the new generation. This means that in the long run, it will not likely become an economic and sociopolitical key figure as it used to be. Its cutting edge of education is now being challenged by one of the most fundamental factors in capitalism-money. By contrast, the U.S. economy has been recently reported "ha[ving] been heading upward", though at a slow pace (Money Morning, 2011, Apr 21). The second implication is that fewer international students will decide to choose the U.K. as their destination for study due to the increased tuition fees. The expensiveness in education will to some degree bar intellectuals from advancing their career in the U.K. Consequently, the dissemination power of British spelling will likewise be undermined. This implication is also in accordance with Graddol's (2006) report on the future of British education, saying "a lower proportion of the revenue from the global ELT [i.e., English language teaching] business will be, in future, entering the UK economy" [italics mine] (p. 123).

As a result, a decision for the American spelling style will likely come naturally. Let's say a publishing house in a non-native English speaking country is choosing a spelling style for its new book-then which spelling style between British English and American English will grant an endowment of getting to a wider audience? A spelling style that allows higher searchability and user-friendliness should certainly be a more promising choice. Note that the quality of familiarity and, thus, customization are also contributing factors in product improvement and good performance, just like the case of the renowned series Harry Potter by J.K. Rowling, in which an American edition for each volume has been introduced "to clarify the text for American readers" (Harry Potter Lexicon, 2005, para. 1). Another example is the book named Read This! 2, a book for young adult ESL students, published by Cambridge University Press, yet with American authors D. Mackey and A. Savage and in American spelling style throughout (Cambridge University Press, 2010). These actual cases confirm the plausible validity of the change-for-American-spelling notion suggested in an earlier section and depict clearly how business and American spelling recognition can enable a company or profit-seeking organization to change their spelling style ad hoc for the good of its business running.

In addition to the publishing circle, educational administrators and curriculum designers are also, sooner or later, to approve the influence of the American spelling and other languagerelated issues to a higher degree. Again, I am not saying that British spelling will disappear, but that its use will be less in amount. Even a British government organization like the British Library itself also recognizes this status quo, saying that:

Prior to WWII, most teaching of English as a foreign language used British English as its model, and textbooks and other educational resources were produced here in the UK for use overseas. This reflected the UK's cultural dominance and its perceived 'ownership' of the English Language [sic]. Since 1945, however, the increasing economic power of the USA and its unrivalled influence in popular culture has meant that American English has become the reference point for learners of English in places like Japan and even to a certain extent in some European countries. British English remains the model in most Commonwealth countries where English is learnt as a second language. However, as the history of English has shown, this situation may not last indefinitely [italics mine] (British Library, n.d., para. 9). 
It is clear that the discussion in this paper is largely in accordance with the quote above. So, the question that might occur to the educators' mind is whether to let the students learn the spelling that comes to them naturally-particularly through new media and the digital world - and is in common use by the majority of the new English-using generation or to adhere to the traditional spelling standard which is gradually decreasing in popularity.

\section{Concluding Remarks}

Throughout this paper, I have argued for American spelling preference by non-native speakers of English in particular, with the aid of new media and emerging social networking supplying the diffusion of thoughts and, of course, the spelling. In Kachru's (1992) model (referred to in Jenkins, 2003), the non-native users of English, be they ESL or EFL users, constitute the majority of the world's English-using population, thereby belittling the significance of native speakers of English in spreading a particular style of spelling. From a survey by Thongkhamkhao (2010), the popularity of American spelling proves positive and has already been established in a country where English is merely a foreign language, indicating that this preference may even be higher in countries where English is used much more frequently. And a reflection from the internet world attests the construct in that American spelling is used simply far more frequently across billions and billions of websites and web pages. This, in turn, suggests that American spelling will be even more widely used in the future when current non-native varieties of English get through nativization and endonormative stabilization in Schneider's (2007) Dynamic Model in the future, since the American spelling will be part of their identity formation.

A few recommendations for further research include a study to explore similar steps of American and British pronunciation. This would clearly show a significant influence of American pronunciation, especially through media in various forms. Another interesting study to me is to explore the actual use of words used differently in the two varieties of English, such as lift vs. elevator and pavement vs. sidewalk. This exploration will in one way show the perception of these lexical differences in non-native users of English.

\section{Acknowledgements}

I would like to give big thanks to Wireka Panchamanont, Ed.D., who kindly read the first draft of this paper and gave valuable comments for improving it. Without her help, it would be much less clear and comprehensive. Also, appreciation goes to Jiaranai Thongkhamkhao, a former student under my supervision. Her senior project, no matter how choosy I was about its development, allows me to empirically start this paper. My heartfelt appreciation also goes to Asst. Prof. Namtip Pingkarawat, Ph.D., who brought me to studies into world Englishes, a field of study with challenging perspectives. Without her, my understanding of the English language might have fallen on some obsolete notions in research. 


\section{References}

Associated Press. (2011). Pa. teen wins National Spelling Bee with 'cymotrichous'. msnbc.com [Online news]. URL http://www.msnbc.com/id/43255742/ns/us news-life/?gt1 $=43001$

Baugh, A.C. \& Cable, T. (1993). A history of the English language $\left({ }^{\text {th }}\right.$ ed.). New Jersey, U.S.: PrenticeHall.

British Library. (n.d.). Minority ethnic English. Sounds familiar? [Online html for learning]. URL http://www.bl.uk/learning/langlit/sounds/case-studies/minority-ethnic/

Bryson, B. (1990). The mother tongue. New York, U.S.: Perennial.

Cambridge University Press. (2010). Read this! Level 2 student's book. Cambridge, U.K.: Cambridge University Press. URL http://www.cambridge.org/aus/catalogue/catalogue.asp?isbn=97805 21747899

Crystal, D. (1997a). The Cambridge encyclopedia of language $\left(2^{\text {nd }}\right.$ ed.). Cambridge, U.K.: Cambridge University Press.

Crystal, D. (1997b). English as a global language. Cambridge, U.K.: Cambridge University Press.

Dewey, M., \& Jenkins, J. (2010). English as a lingua franca in the global context: Interconnectedness, variation and change. In M. Saxena, \& T. Omoniyi (Eds.), Contending with globalization in world Englishes (pp. 72-92). Bristol, U.K.: Multilingual Matters.

Graddol, D. (2006). English next. U.K.: British Council.

Harrison, A. (2010, Dec 10). Universities prepare to raise fees amid protest pledge. BBC News [Online html]. URL http://www.bbc.co.uk/news/education-11967809

Harry Potter Lexicon. (2005). Differences: Harry Potter books [Online html]. URL http://www.hp-lexicon.org/about/books/differences.html

Jenkins, J. (2003). World Englishes. London: Routledge.

Jones, S. (2001). List of American vs. British spelling. In P. Byrd, English Grammar on the Web, Department of applied linguistics \& ESL, Georgia State University [Online learning resource]. URL http://www2.gsu.edu/ wwwesl/egw/jones/spelling.htm

Kongsuwannakul, K. (2005). Characteristic features in English acknowledgements written by Thai graduates: Indicators for Thai English (Master's thesis). Chulalongkorn University, Bangkok, Thailand.

Lewis, M. P. (Ed.). (2009). Ethnologue: Languages of the world (16th ed.). Texas, U.S.: SIL International. URL http://www.ethnologue.com

Longman Exams Dictionary. (2006). Essex, England: Pearson Education.

Matichon Online. (2011, June 30). When anthropologists analyze love, sex, self, and community in the Facebook world. Front page [Online html, in Thai]. URL

http://www.matichon.co.th/news_detail.php?newsid=1309346305\&grpid=01\&catid=\&sub catid $=$

Matichon Online. (2011, July 5). China's biggest search engine company cooperates with Microsoft for taking the global market share from Google. Front page [Online html, in Thai]. URL http://www.matichon.co.th/news_detail.php?newsid=1309859594\&grpid=\&catid=09\& subcatid $=0904$

Merriam-Webster. (2011). 200 ${ }^{\text {th }}$ anniversary-1806-2006. About Us [Online html]. URL http://www.merriam-webster.com/info/webster-reform.htm

Moeller, S. (2011, May 24). Net shift: Young adults don't follow news, it follows them. The Nation, p. 14A.

Money Morning. (2011, Apr 21). Slowing U.S. Economic Recovery Faces Strong Headwinds in 2011. The Market Oracle [Online html]. URL http://www.marketoracle.co.uk/Article27682.html

Omoniyi, T., \& Saxena, M. (2010). Introduction. In M. Saxena, \& T. Omoniyi (Eds.), Contending with globalization in world Englishes (pp. 1-22). Bristol, U.K.: Multilingual Matters.

Paton, G. (2010, Nov 19). Education: Pupils will lose marks for poor grammar and spelling. The Telegraph [Online news], URL http://www.telegraph.co.uk/education/educationnews/ 
8148093/Education-pupils-will-lose-marks-for-poor-grammar-and-spelling.html

Pearson Longman. (n.d.). Longman corpus network [Online html]. URL http://www.pearsonlongman.com/dictionaries/corpus/

Population Reference Bureau. (2010). 2010 world population data sheet [Online pdf]. URL http://www.prb.org/pdf10/10wpds_eng.pdf

Schneider, E. W. (2007). Postcolonial English: Varieties around the world. Cambridge, U.K.: Cambridge University Press.

Tapia, A.T. (2010). Non-native English speakers setting new standard. New America media [Online pdf]. URL http://www.globalenglish.com/m/about/news/dl/GE-NewAmericaMedia-07042 010.pdf

Thomson Reuters. (2011). Times Higher Education's world university rankings 2010 [Online html]. URL http://www.timeshighereducation.co.uk/world-university-rankings/2010-2011/top-200. html\#score_OS\%7Csort_region\%7Creverse_false

Thongkhamkhao, J. (2010). British and American spelling styles: The futuristic prediction of global English spelling. Unpublished manuscript, Mae Fah Luang University, Chiang Rai, Thailand. Upward, C. (Comp.). (1997). American spellings for British schools? A submission from the Simplified Spelling Society to the School Curriculum and Assessment Authority (SCAA). Journal of the Simplified Spelling Society, 21(1), 31-32. URL http://www.englishspellingsociety.org/ journals/j21/usforuk.php

\section{About the Author}

\section{Kunlaphak Kongsuwannakul}

I graduated from Chulalongkorn University, majoring in Secondary Education (English and German) for my B.Ed. and in English for my M.A. My thesis is "Characteristic Features in English Acknowledgements Written by Thai Graduates: Indicators for Thai English," which is a study under the theory of world Englishes. Therefore, my interests lie in characteristics of new Englishes, English language and teaching, and applied corpus linguistics. I am a lecturer at the School of English, Institute of Social Technology, Suranaree University of Technology, Nakhon Ratchasima 30000, Thailand. 